\title{
A LETTER TO THE EDITOR: VITAMIN D DEFICIENCY LEADS TO ELEVATED PTH LEVELS AND TO DECREASED BONE DENSITY
}

\author{
By Amos Gelbard*
}

Email: amosgelbard@gmail.com

Received: 11 January 2021, Revised and Accepted: 02 February 2021

(C) 2021 The Authors. Published by Innovare Academic Sciences Pvt Ltd. This is an open access article under the CC BY license (http://creativecommons. org/licenses/by/4.0/] DOI: http://dx.doi.org/10.22159/ijms.2021v9i2.40758. Journal homepage: https://innovareacademics.in/journals/index.php/ijms

Parathyroid hormone (PTH) is secreted in the parathyroid glands. It has a role in bone remodeling, a process in which calcium transfers from the bone to the blood stream and back to the bone. As PTH levels rise, more calcium is released from the bones to the blood, as levels decrease, calcium re-accumulates in the bones. It is thought that PTH is secreted in response to low blood serum calcium levels to maintain them, but here we propose that PTH levels are directly and inversely related to Vitamin D levels. This has implications for several illnesses including low bone mineral density (BMD) and osteoporosis.

The following research [1] shows the negative correlation between Vitamin D levels and serum PTH: "Serum PTH correlated negatively with serum 250HD (Vitamin D). This significant negative correlation was observed in all regions. When serum 250 HD was $<25,25-50$, or more than $50 \mathrm{nmol} / \mathrm{L}$, respectively, mean serum PTH levels were 4.8, 4.1 , and $3.5 \mathrm{pmol} / \mathrm{L}$, respectively.... [1]"

Another study, by Dhanwal et al. [2] found a negative correlation between PTH levels and Vitamin D levels and a positive correlation between Vitamin D levels and BMD. They conclude that "hyperthyroid patients with concomitant Vitamin D deficiency had lower BMD compared with Vitamin D-sufficient patients [2]."

Another study of Postmenopausal Osteoporotic Women [3] found them to be severely deficient in Vitamin D. "Mean serum 25(OH)D level was 26.8 and overall, $64 \%$ of women had serum levels $<30 \mathrm{ng} \mathrm{mL}-1$." They also observed the negative correlation between Vitamin D and PTH levels [3].
A study [4] examining treatment of sodium fluoride, Vitamin D and Calcium found "an increase in new bone formation in all patients." They conclude that "In order to restore bone mass in osteoporotic subjects, a therapeutic regimen of $50 \mathrm{mg}$ of sodium fluoride and at least 900 mg of calcium per day and 50,000 units of Vitamin D twice weekly is recommended [4]."

To conclude, it seems that decreased levels of Vitamin D lead to hyperparathyroidism and therefore to reduction in BMD. It is advised to continue studying Vitamin D for its relationship with PTH and for its possible role in the treatment and prevention of osteoporosis and low BMD status.

\section{REFERENCES}

1. Lips P, Duong T, Oleksik A, Black D, Cummings S, Cox D, et al. A global study of Vitamin D status and parathyroid function in postmenopausal women with osteoporosis: Baseline data from the multiple outcomes of raloxifene evaluation clinical trial. J Clin Endocrinol Metab 2001;86:1212-21.

2. Dhanwal DK, Kochupillai N, Gupta N, Cooper C, Dennison EM. Hypovitaminosis D and bone mineral metabolism and bone density in hyperthyroidism. J Clin Densitom 2010;13:462-6.

3. Lips P, Hosking D, Lippuner K, Norquist JM, Wehren L, Maalouf G, et al. The prevalence of Vitamin D inadequacy amongst women with osteoporosis: An international epidemiological investigation. J Intern Med 2006;260:245-54.

4. Jowsey J, Riggs BL, Kelly PJ, Hoffman DL. Effect of combined therapy with sodium fluoride, Vitamin D and calcium in osteoporosis. Am J Med 1972;53:43-9. 